\title{
AKTIVITAS EKSTRAK TEMULAWAK (Curcuma xanthorrhiza Roxb.) TERHADAP PROLIFERASI DAN DIFERENSIASI SEL OTAK BESAR ANAK TIKUS BERUMUR TIGA HARI SECARA IN VITRO
}

\author{
Min Rahminiwati $^{1,3}$, Ita Juwita ${ }^{2}$, Ani Murtisari ${ }^{2}$, Latifah K Darusman ${ }^{3}$ \\ ${ }^{1)}$ Bagian Farmakologi, Departemen AFF-FKH IPB \\ ${ }^{2)}$ Bagian Anatomi, Departemen AFF-FKH IPB \\ 3) Pusat Studi Biofarmaka LPPM IPB \\ Email : minrahminiwati@yahoo.com
}

\begin{abstract}
ABSTRAK
Kurkumin yang terdapat dalam rimpang temulawak, selain dapat menginduksi terjadinya proliferasi sel progenitor pada otak tikus dewasa juga dapat menghambat kerja enzim tirosinkinase yang berperan penting dalam mengatur pertumbuhan dan diferensiasi sel. Meskipun demikian respon sel saraf terhadap ekstrak temulawak pada masa pertumbuhan perlu kajian lebih lanjut. Efek ekstrak temulawak terhadap proliferasi dan diferensiasi sel otak besar atau serebrum pada masa pertumbuhan anak diteliti pada sel otak anak tikus Spague Dawley berumur tiga hari yang ditumbuhkan dalam media DMEM (Dulbecco's Modified Eagle's Medium). Perlakuan dikelompokkan dalam kelompok kontrol positif (mDMEM $+30 \mu \mathrm{g} / \mathrm{mL}$ asiaticoside (AC), kontrol negatif (mDMEM), kelompok yang memperoleh ekstrak temulawak (CZ) 100 ppm (mDMEM+100 ppm CZ), CZ 200 ppm (mDMEM+200 ppm CZ), dan CZ 400 ppm (mDMEM+400 ppm CZ). Kultur diinkubasi pada suhu $37^{\circ} \mathrm{C}$ dalam inkubator $\mathrm{CO}_{2} 5 \%$ selama 6 hari. Parameter yang diamati adalah population doubling time, komposisi sel saraf dan sel glia, panjang akson dan dendrite yang diukur masing masing menggunakan hemositometer, pewarnaan Hematoxyilin Eosin (HE) dan mikrometer. Hasil penelitian menunjukkan ekstrak temulawak pada konsentrasi 100 ppm memperlambat prolfperasi, pada konsentrasi $400 \mathrm{ppm}$ meningkatkan diferensiasi sel yang ditunjukkan dengan meningkatnya ratio sel glia terhadap sel saraf dan mempengaruhi panjang akson dan dendrite.
\end{abstract}

Kata kunci : Curcuma xanthorrhiza Roxb., neuron, sel glia, dendrite

\section{PENDAHULUAN}

Otak merupakan organ tubuh yang mempunyai peran sangat penting dalam mengatur dan mengontrol semua aktivitas tubuh termasuk perilaku, tumbuh kembang dan reproduksi. Sel-sel penyusun otak manusia sekitar $90 \%$ terdiri dari sel-sel glial dan sisanya yaitu sekitar $10 \%$ adalah sel saraf. Sebagai sel penyangga, sel glia berfungsi melindungi, merawat, dan menjadi sumber nutrisi sel saraf (Ramos \& Shen, 2008)

Sel yang termasuk sel glia adalah astrosit, oligodendrosit, mikroglia dan sel ependimal. Astrosit berperan dalam mempertahankan sirkulasi darah di otak, mengatur kadar ion dan nutrien, memperbaiki dan mencegah jaringan saraf dari kerusakan. Oligodendrosit bekerja melapisi akson dengan menghasilkan myelin. Sel ependimal memproduksi cairan serebrospinal dan sel. Mikroglia melakukan fagositosis terhadap sel-sel otak yang mati dan bakteri (Junqueira \& Carnerio, 2005).

Kerusakan sel saraf akibat aging atau peradangan dapat menyebabkan terjadinya perubahan komposisi sel saraf dan sel glia. Hal ini akan memicu terjadinya gangguan fungsi otak seperti yang terjadi pada penyakit alzheimer (Choi, 2011).

Alzheimer adalah penyakit yang muncul karena adanya kerusakan sel saraf otak di hipokampus dan kortek serebrum. Kedua bagian otak ini berkaitan dengan aktivitas memori sehingga timbulnya alzheimer seringkali ditandai dengan 
adanya dementia atau kepikunan dengan tingkat keparahan penyakit bervariasi tergantung pada derajat kerusakan otak. Selain terjadinya perubahan komposisi sel saraf dan sel glia, gangguan fungsi otak juga bisa terjadi karena adanya kelainan pada akson. Kerusakan akson menyebabkan penyampaian impuls saraf di otak mengalami hambatan (Braak et al., 2006).

Beberapa tanaman diantaranya adalah pegagan dan temulawak dilaporkan mempunyai potensi sebagai pelindung sel saraf otak. Salah satu senyawa kimia dari pegagan yang berpotensi sebagai neuroprotektor adalah asiaticoside. Asiaticoside bekerja mempercepat regenerasi sel akson dan menghambat pembentukan beta amyloid yaitu suatu metabolit protein yang menyebabkan terjadinya kerusakan sel saraf (Soumyanath, 2005).

Senyawa lainnya adalah kurkumin dan xanthorrhizole. Kedua senyawa ini merupakan komponen utama dalam temulawak. Kurkumin adalah antiinflamasi dan neuroprotektor yang potensial. Sebagai antiinflamasi, senyawa kurkumin bekerja menghambat kerusakan otak yang lebih parah akibat aktivitas mediator kimia yang dilepaskan oleh mikroglia pada waktu terjadinya proses fagositosis benda-benda asing di otak (Jayaprakasha, 2006). Potensi kurkumin dalam melindungi dan memperbaiki sel otak juga ditunjukkan oleh kemampuannya dalam menginduksi peningkatan proliferasi sel progenitor otak tikus dewasa (Kim et al., 2008).

Hazama (1994) telah berhasil mengidentifikasi keterlibatan enzim tirosin kinase dalam melakukan aktivitas proliferasi dan diferensiasi sel. Enzim ini mengatur proses proliferasi sel-sel kanker dan juga sel glia sehingga adanya hambatan terhadap aktivitas enzim tirosin kinase dapat menyebabkan terjadinya hambatan terhadap proliferasi sel seperti dilaporkan oleh Hong et al. (1999), Handayani (2008) dan Cheah et al. ( 2006).
Hong dan Handayani melaporkan bahwa efek antiproliferasi kurkumin dan xanthorrhizole terhadap sel kanker terkait dengan aktivitas inhibisinya terhadap enzim tirosin kinase. Adapun interferensi xanthorrhizole terhadap sel nomal dilaporkan oleh Cheah et al. (2006) yang melihat adanya gangguan proliferasi dan diferensiasi sel hati dan sel ginjal monyet normal pada paparan dengan xanthorrhizole.

Aktivitas farmakologi ekstrak temulawak, berdasarkan uraian diatas, bersifat mendua. Selain bersifat sebagai neuroprotektor melalui daya induksinya terhadap proliferasi sel progenitor otak, ekstrak temulawak juga berpotensi sebagai inhibitor perkembangan sel yang terkait dengan aktivitasnya sebagai inhibitor enzim tirosin kinase. Meskipun demikian, pengaruh ekstrak temulawak, terhadap diferensiasi dan proliferasi sel otak pada masa pertumbuhan belum diketahui. Oleh karena itu penelitian ini ditujukan untuk meneliti respons sel otak serebrum in vitro pada anak tikus yang berumur 3 hari terhadap ekstrak temulawak. Parameter yang diamati meliputi proliferasi dan diferensiasi sel otak serta pertumbuhan akson dan dendrite.

Serebrum adalah bagian terbesar dari otak yang berperan dalam menginterpretasikan informasi sensoris, menginisiasi rangsangan pada otot rangka, mengintegrasikan aktivitas sel saraf yang berhubungan dengan komunikasi, ekspresi respon emosional, belajar, memori, daya ingat, dan kebiasaan lainnya yang dilakukan secara sadar (Colville \& Bassert, 2002).

\section{METODE PENELITIAN Bahan}

Otak besar dari tikus putih (Rattus norvegicus) strain Sprague Dawley yang berumur tiga hari (newborn), gelatin $0,1 \%$, larutan pencuci phosphate buffered saline (PBS) yang ditambahkan gentamisin 50 $\mu \mathrm{g} / \mathrm{mL}$ dan newborn calf serum (NBCS) 
0,1\% (mPBS), medium kultur mDMEM yaitu DMEM (Dulbecco's Modified Eagle's Medium) yang dimodifikasi dengan penambahan asam amino nonesensial (AANE) 10\%, gentamisin 50 $\mu \mathrm{g} / \mathrm{mL}$, sodium bikarbonat $3,7 \mu \mathrm{g} / \mathrm{mL}$, dan newborn calf serum (NBCS) 10\%; asiaticoside (AC) $30 \mu \mathrm{g} / \mathrm{mL}$, ekstrak rimpang temulawak (CZ), dan pewarna Hematoksilin Eosin (HE).

\section{Alat}

Cawan petri steril (Corning $^{\circledR}$ ), gelas beker, gelas ukur. Tabung konikal, tabung mikro, peralatan bedah steril, mikropipet, tip, biosafety cabinet, mikrofilter, disposible syringe $1 \mathrm{~mL}$, sentrifuge, object glass, cover glass, hemositometer, inkubator, mikroskop, spatula, dan timbangan digital.

\section{Cara Kerja}

\section{Pembuatan Ekstrak Rimpang Temulawak}

Ekstrak rimpang temulawak yang dipakai pada penelitian ini adalah ekstrak etanol $30 \%$ yang diperoleh dengan cara maserasi dingin. Ekstrak diperoleh dari Pusat Study Biofarmaka LPPM IPB.

\section{Persiapan Kultur Sel Saraf Otak Besar}

Sebelum digunakan, cawan petri dilapisi dengan $1 \mathrm{~mL}$ gelatin $0,1 \%$ dan didiamkan pada suhu kamar selama 1 jam. Setelah satu jam, gelatin dibuang dan dicuci dengan PBS kemudian didiamkan selama 5 menit. Cawan petri diisi dengan mDMEM dan perlakuan (asiaticoside 30 $\mu \mathrm{g} / \mathrm{mL}$, ekstrak rimpang temulawak (CZ) konsentrasi 100, 200, dan 400 ppm sebanyak $2 \mathrm{~mL}$ kemudian diinkubasi selama minimal satu jam ke dalam inkubator $\mathrm{CO}_{2} 5 \%$ pada suhu $37^{\circ} \mathrm{C}$.

\section{Isolasi dan Kultur Sel Saraf Otak Besar}

Sel saraf otak besar tikus (Rattus norvegicus) umur 3 hari diisolasi, dan disuspensi di dalam larutan mPBS kemudian disentrifugasi dengan kecepatan 210 g selama 10 menit. Proses pencucian dilakukan dengan mPBS sebanyak empat kali dan mDMEM sebanyak satu kali. Sel dengan konsentrasi $6,5 \times 10^{4} \quad \mathrm{sel} / \mathrm{mL}$ kemudian dimasukkan ke dalam cawan petri yang berisi mDMEM dan perlakuan sebanyak $2 \mathrm{~mL}$. Setiap kultur dilakukan duplo, terdiri atas cawan yang dilapisi dan tidak dilapisi cover glass. Cawan yang dilapisi cover glass digunakan untuk pewarnaan $H E$. Kultur diinkubasi di dalam inkubator $\mathrm{CO}_{2} 5 \%$ pada suhu $37^{\circ} \mathrm{C}$. Medium mDMEM dan perlakuan diganti setiap 2 hari sekali sebanyak $2 \mathrm{~mL}$ setiap penggantian. Kultur dilakukan sampai hari keenam.

\section{Evaluasi Hasil Kultur Sel Saraf Tingkat Proliferasi Berdasarkan Population Doubling Time (PDT)}

Tingkat proliferasi ditentukan dengan menghitung selisih jumlah sel saraf pada saat sebelum dikultur dan setelah kultur pada hari keenam. Untuk menghitung jumlah sel, medium sel dibuang kemudian sel dicuci dengan mPBS. Larutan tripsin $0,1 \%$ dalam mPBS sebanyak $1 \mathrm{~mL}$ dimasukan kedalam sel tersebut kemudian sel diinkubasi selama 5 menit sampai sel terlihat soliter. Sel yang telah terdisosiasi disentrifugasi di dalam mPBS, selanjutnya sel dihitung dibawah mikroskop menggunakan hemositometer Improved Neubauer dengan perhitungan :

Total sel $(\mathrm{sel} / \mathrm{mL})=$ jumlah sel pada 5 kotak $\mathrm{x}$ faktor pengenceran $\mathrm{x} 10^{4}$

Population Doubling Time (PDT) dihitung menggunakan rumus:

PDT (hari) $=\frac{1}{\frac{\log \text { jumlah sel akhir-log jumlah sel awal) } \times 3,32}{\text { Waktu }}}$

\section{Diferensial Sel Untuk Menentukan Sel Saraf dan Sel Glia}

Jumlah sel dihitung dengan metode pewarnaan HE. Kultur sel yang 
ditumbuhkan di atas cover glass dicuci dengan PBS kemudian difiksasi dalam larutan buffer paraformaldehid $4 \%$ selama 24 jam. Kultur yang telah difiksasi disimpan dalam alkohol $70 \%$ sampai dilakukan pewarnaan HE. Pewarnaan dimulai dengan merendam hasil kultur sel saraf ke dalam alkohol $50 \%$ selama 3 menit. Setelah itu sediaan direndam dalam aquadest selama 5 menit, dalam Hematoxylin 10 menit, dan dibilas dengan aquades selama 5 menit. Selanjutnya sediaan direndam dalam eosin selama 5 menit, dibilas dengan aquades selama 5 menit, dan dilakukan dehidrasi bertingkat menggunakan alkohol 70\%, 80\%, 90\%, $96 \%, 100 \%$ (absolut) tiga kali, masingmasing selama 10 menit dan dilanjutkan dalam xylol dua kali ulangan masingmasing selama 10 menit, kemudian cover glass ditempelkan dengan object glass menggunakan entelan. Penghitungan jumlah sel-sel saraf dan sel-sel glia dilakukan dibawah mikroskop dengan perbesaran 40x10.

\section{Pertumbuhan Panjang Akson dan Dendrit}

Pengamatan pertumbuhan panjang akson dan dendrit melalui pengamatan natif pada hari keenam. Kultur sel saraf difoto sebanyak 4 lapang pandang dengan pembesaran 10x10. Panjang akson dan dendrit diukur dengan menggunakan perangkat lunak image.

\section{Rancangan Percobaan}

Penelitian dilakukan terhadap lima kelompok perlakuan yang terdiri dari kontrol positif (mDMEM+asiaticoside 30 $\mu \mathrm{g} / \mathrm{mL}$ ), kontrol negatif (mDMEM), CZ 100 ppm (mDMEM+CZ 100 ppm), CZ 200 ppm (mDMEM+CZ 200 ppm), CZ 400 ppm (mDMEM+CZ 400 ppm). Masingmasing kelompok perlakuan terdiri atas satu cawan yang dilapisi cover glass untuk pewarnaan HE dan satu cawan tanpa cover glass untuk menghitung Population Doubling Time (PDT). Masing-masing perlakuan dilakukan sebanyak tiga kali ulangan. Parameter yang diamati yaitu PDT, jumlah sel saraf dan sel glia, serta panjang akson dan dendrit. Data PDT serta panjang akson dan dendrit dianalisis menggunakan uji statistik ANOVA dan Duncan.

\section{HASIL DAN PEMBAHASAN}

\section{Tingkat Proliferasi Berdasarkan} Population Doubling Time (PDT)

Population Doubling Time (PDT) adalah waktu yang diperlukan oleh populasi sel untuk menjadikan jumlahnya menjadi dua kali lipat dari jumlah semula. Proliferasi sel yang cepat ditunjukkan dengan PDT yang rendah. Hasil PDT kultur sel saraf yang diberi perlakuan ekstrak rimpang temulawak dibandingkan dengan kontrol disampaikan pada Tabel 1.

Tabel 1. Tingkat PDT sel saraf yang tumbuh pada masing-masing perlakuan

\begin{tabular}{ccccc}
\hline \multirow{2}{*}{$\begin{array}{c}\text { Kontrol } \\
\text { positif }\end{array}$} & $\begin{array}{c}\text { Kontrol } \\
\text { negatif }\end{array}$ & $100 \mathrm{ppm}$ & $200 \mathrm{ppm}$ & $400 \mathrm{ppm}$ \\
\cline { 3 - 5 } $3,27 \pm 0,26^{\mathrm{a}}$ & $3,78 \pm 0,51^{\mathrm{a}}$ & $4,39 \pm 0,52^{\mathrm{b}}$ & $5,15 \pm 0,99^{\mathrm{b}}$ & $6,62 \pm 0,57^{\mathrm{c}}$ \\
\hline
\end{tabular}

Keterangan: Huruf superscript yang berbeda pada baris yang sama menunjukkan adanya perbedaan nyata $(\mathrm{P}<0,05)$. Kontrol positif (mDMEM+asiaticoside (AC) $30 \mu \mathrm{g} / \mathrm{mL}$ ); kontrol negatif (mDMEM); ekstrak rimpang temulawak (Curcuma xanthorrhiza Roxb.) (CZ) 100 ppm (mDMEM+CZ 100 ppm); CZ 200 ppm (mDMEM+CZ 200 ppm) dan CZ $400 \mathrm{ppm}(\mathrm{mDMEM}+\mathrm{CZ} 400 \mathrm{ppm})$

Berbeda dengan nilai PDT sel otak pada medium yang mengandung ekstrak asiaticoside, nilai PDT sel otak pada medium yang mengandung ekstrak 
temulawak konsentrasi CZ 100 ppm, 200 ppm, dan 400 ppm berturut-turut adalah 4,39 \pm 0,52 hari, 5,15 $\pm 0,99$ hari, dan 6,62 $\pm 0,57$ hari. Nilai PDT kelompok ini secara signifikan lebih tinggi dibandingkan dengan kontrol positif dan kontrol negatif $(\mathrm{P}<0,05)$. Hal ini menunjukkan adanya hambatan terhadap proliperasi sel sel otak. Semakin tinggi konsentrasi temulawak yang ditambahkan, hambatan semakin besar dan proliperasi sel otakpun semakin lambat.

\section{Komposisi Jumlah Sel Saraf dan Sel Glia}

Sel glia merupakan sel-sel yang berfungsi untuk menjaga, memelihara, mendukung dan sumber nutrisi sel saraf. Sel glia menyusun $40 \%$ volume otak dan medulla spinalis (Feriyawati, 2006). Sedangkan menurut Junqueira \& Carneiro (2005) seluruh otak memiliki jumlah sel glia 10 kali lebih banyak dibandingkan sel saraf pada keadaan in vivo. Persentase jumlah sel saraf dan sel glia pada masingmasing perlakuan dapat dilihat pada Tabel 2.

Diferensiasi sel ditunjukkan oleh perbandingan jumlah sel saraf dengan sel glia. Tabel 2 menunjukkan perbandingan antara sel saraf dengan sel glia pada kontrol negatif adalah 47,20\% dan 52,80\%. Hasil ini hampir sama dengan hasil penelitian Riyacumala (2010) yang memberikan nilai komposisi sel saraf dengan sel glia pada mDMEM adalah $48,50 \%$ dan 51,50\%. Adapun kultur sel saraf yang mengandung asiaticoside (kontrol positif) menunjukkan persentase sel saraf lebih tingi dibandingkan sel glia yang berbeda secara signifikan dengan kontrol negatif.

Diferensiasi sel otak pada medium yang mengandung temulawak lebih banyak mengarah pada pembentuk sel glia daripada sel saraf. Semakin tinggi konsentrasi temulawak yang ditambahkan, prosentase jumlah sel saraf yang terbentuk semakin sedikit dan sel glia sebaliknya jumlahnya semakin banyak. Perbedaan yang signifikan dengan kontrol positif dan negatif mulai terjadi pada konsentrasi 200 ppm dan peningkatan prosentase sel glia tertinggi terjadi pada perlakuan CZ 400 ppm sebanyak 62,75\%. Data ini mengindikasikan bahwa sel otak yang terpapar ekstrak temulawak cenderung berdiferensiasi membentuk sel glia dibandingkan dengan sel saraf.

Sel glia yang terdapat di sistem saraf pusat adalah astrosit, oligodendrosit, mikroglia, dan sel ependimal. Dari keempat macam sel glia tersebut, sel glia yang ditemukan pada kultur sel saraf hanyalah tiga yaitu astrosit, oligodendrosit, dan mikroglia. Sel ependimal tidak ditemukan pada kultur ini karena sel melapisi dinding ventrikel otak. Astrosit memiliki inti yang paling besar dan bulat dengan badan sel astrosit berbentuk bintang. Oligodendrosit memiliki ukuran inti yang lebih kecil dibandingkan dengan inti astrosit dan memiliki penjuluran lebih sedikit dan kecil. Mikroglia memiliki inti sel kecil, bulat, dan dikelilingi dengan banyak penjuluran kecil (Junqueira \& Carnerio, 2005). Morfologi ketiga sel glia tersebut dapat dilihat pada Gambar 1.

Tabel 2. Persentase sel saraf dan sel glia pada masing-masing perlakuan

\begin{tabular}{lccccc}
\hline Jenis & Kontrol & Kontrol & \multicolumn{3}{c}{ Konsentrasi CZ } \\
\cline { 4 - 6 } sel & positif & negatif & $100 \mathrm{ppm}$ & $200 \mathrm{ppm}$ & $400 \mathrm{ppm}$ \\
\hline $\begin{array}{l}\text { Sel } \\
\text { saraf }\end{array}$ & $69,03 \pm 3,47^{\mathrm{c}}$ & $47,20 \pm 9,96^{\mathrm{b}}$ & $45,11 \pm 2,44^{\mathrm{ab}}$ & $36,18 \pm 0,20^{\mathrm{a}}$ & $37,25 \pm 4,43^{\mathrm{a}}$ \\
\hline Sel glia & $30,97 \pm 3,47^{\mathrm{a}}$ & $52,80 \pm 9,96^{\mathrm{b}}$ & $54,88 \pm 2,44^{\mathrm{bc}}$ & $63,81 \pm 0,20^{\mathrm{c}}$ & $62,75 \pm 4,43^{\mathrm{c}}$ \\
\hline \multicolumn{2}{l}{ Huruf superscript yang berbeda pada baris yang sama menunjukkan adanya perbedaan nyata $(\mathrm{P}<0.05)}$.
\end{tabular}



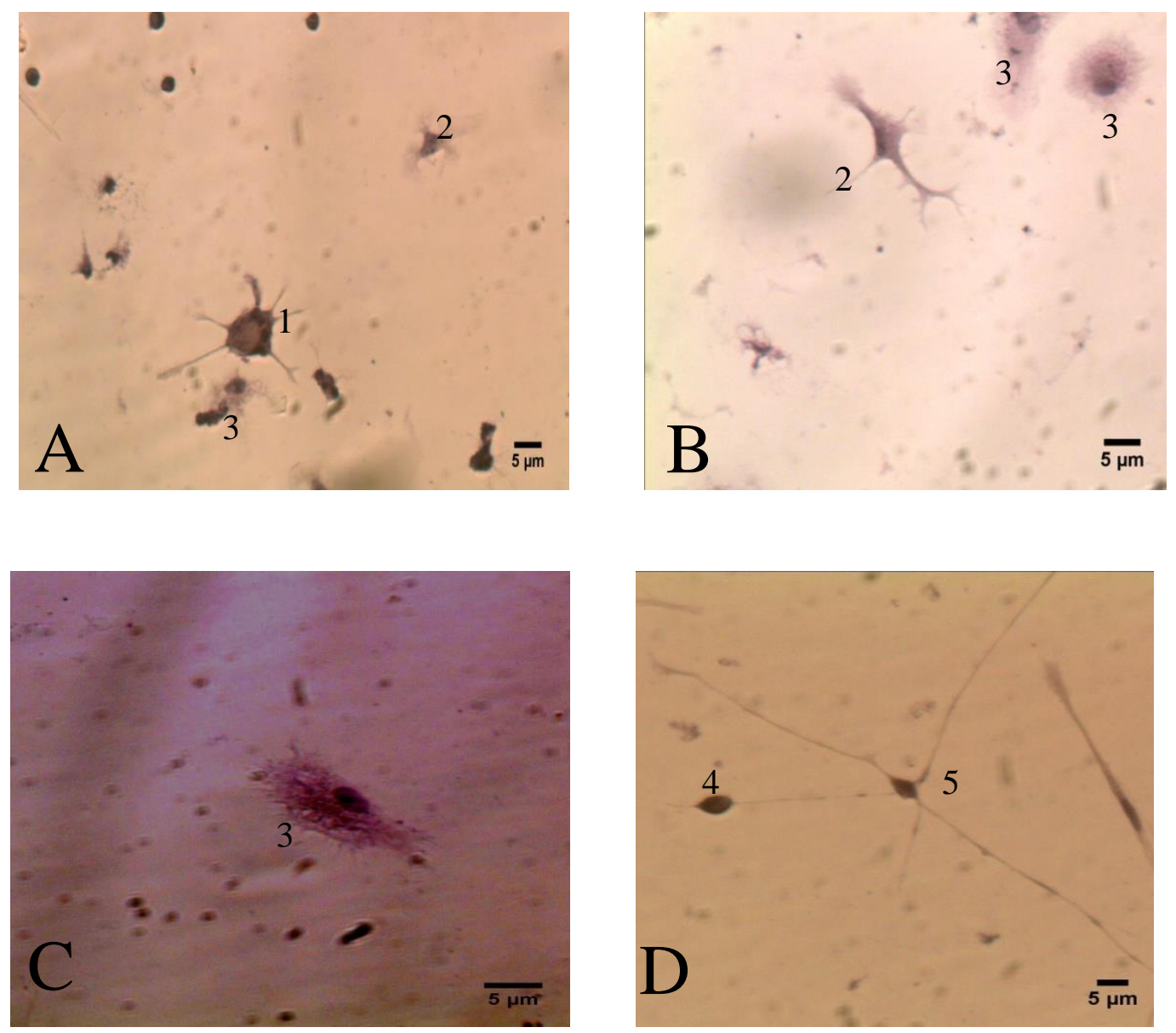

Gambar 1. Morfologi sel glia dan sel saraf

Keterangan: Sel glia (A, B, C). Astrosit (1), oligodendrosit (2), mikroglia (3). Sel saraf (D).

Sel saraf bipolar (4), sel saraf multipolar (5), Pewarnaan HE. Bar: $5 \mu \mathrm{m}$.

Salah satu sel glial yaitu astrosit mempunyai peran penting dalam mengatur neurogenesis. Sebagai progenitor otak (Goldman, 2003) astrosit memiliki kemampuan untuk mendukung partumbuhan dendrit (Le Roux \& Reh, 1994).

Neural Progenitor Cell (NPC) merupakan sumber perkembangan sel saraf dan sel glia yang membentuk semua bagian otak pada perkembangan embrio. NPC bersifat mampu membelah, migrasi, dan berdiferensiasi menjadi neuron (Kim et al., 2008). Menurut Kalverbour et al. (1999), progenitor sel saraf akan berkembang menjadi sel saraf dan penjulurannya akan membentuk akson dan dendrit. Ukuran panjang akson dan dendrit pada medium dasar (mDMEM) berdasarkan penelitian Riyacumala (2010) adalah berkisar
$167,7 \mu \mathrm{m}$ dan $102,5 \mu \mathrm{m}$, sedangkan pada penelitian ini panjang akson dan dendrit hanya berkisar $20,90 \mu \mathrm{m}$ dan $13,81 \mu \mathrm{m}$. Ukuran panjang akson dan dendrit yang lebih pendek disebabkan karena sel saraf yang tumbuh yaitu progenitor sel saraf. Progenitor sel saraf memiliki penjuluran yang pendek. Selain itu, pengukuran pada penelitian Riyacumala (2010) dilakukan pada hari kesebelas sedangkan pada penelitian ini pengukuran dilakukan pada hari keenam sehingga mempengaruhi panjang akson dan dendrit yang terbentuk.

\section{Pertumbuhan Panjang Akson Dan Dendrit}

Akson dan dendrit merupakan penjuluran sel saraf yang berfungsi untuk menghantarkan impuls (Kuntarti, 2007). 
Tabel 3. Panjang akson dan dendrit pada masing-masing perlakuan $(\mu \mathrm{m})$

\begin{tabular}{lccccc}
\hline & \multirow{2}{*}{$\begin{array}{c}\text { Kontrol } \\
\text { Positif }\end{array}$} & $\begin{array}{c}\text { Kontrol } \\
\text { negatif }\end{array}$ & \multicolumn{3}{c}{ Konsentrasi CZ } \\
\cline { 3 - 5 } & & & $100 \mathrm{ppm}$ & $200 \mathrm{ppm}$ & $400 \mathrm{ppm}$ \\
\hline Akson & $19,78 \pm 4,25^{\mathrm{ab}}$ & $18,44 \pm 2,99^{\mathrm{a}}$ & $18,72 \pm 1,50^{\mathrm{a}}$ & $17,78 \pm 1,79^{\mathrm{a}}$ & $20,90 \pm 0,01^{\mathrm{b}}$ \\
\hline Dendrit & $10,07 \pm 2,04^{\mathrm{a}}$ & $10,93 \pm 1,04^{\mathrm{a}}$ & $10,35 \pm 2,25^{\mathrm{a}}$ & $11,66 \pm 4,07^{\mathrm{b}}$ & $13,81 \pm 0,64^{\mathrm{b}}$ \\
\hline
\end{tabular}

Akson umumnya memiliki ukuran lebih panjang daripada dendrit. Pertumbuhan panjang akson dan dendrit pada masingmasing perlakuan dapat dilihat pada Tabel 3.

Sel saraf pada medium yang ditambahkan ekstrak rimpang temulawak CZ 400 ppm memiliki akson dan dendrit yang lebih panjang dibandingkan dengan kontrol baik kontrol negatif maupun kontrol positif. Data pada table 1 menunjukan sel saraf pada medium yang ditambahkan ekstrak rimpang temulawak CZ 400 ppm memiliki nilai PDT yang tinggi yaitu sebesar 6,62 $\pm 0,57$ hari. Nilai PDT yang tinggi mengindikasikan perlambatan proliferasi sel saraf dan akibat dari lambatnya proliferasi sel adalah terjadinya peningkatan pertumbuhan akson dan dendrit karena semua energi menjadi lebih banyak terpusat pada pertumbuhan akson dan dendrit. Asiaticoside pada konsentrasi $30 \mu \mathrm{g} / \mathrm{mL}$ memberikan pengaruh yang signifikan terhadap proliferasi dan diferensiasi sel tetapi terhadap dua parameter lainnya efeknya tidak berbeda secara signifikan dengan kontrol. Asiatiscoside dilaporkan dapat memperpanjang akson (Sushma et al., 2010), akan tetapi pada penelitian ini efek tersebut tidak terbukti.

Pernyimpanan memori bergantung pada jumlah percabangan dendrit dan ukuran badan sel saraf (Putranto, 2009). Semakin banyak percabangan dendrit makin besar kemungkinan untuk melakukan sinaps dengan sel saraf lain. Sinaps merupakan titik temu antara sel saraf satu dengan sel saraf lainnya. Semakin banyak sinaps antar sel saraf maka kemampuan otak untuk menampung infromasi yang masuk menjadi lebih banyak pula (Affari, 2011). Pemberian ekstrak rimpang temulawak CZ 400 ppm pada kultur sel otak besar memiliki dendrit yang panjang. Semakin panjang dendrit akan semakin luas jangkauannya sehingga semakin banyak sinaps antar sel saraf. Banyaknya sinaps antar sel mengakibatkan kemampuan otak untuk menampung informasi meningkat menjadi lebih besar.

\section{SIMPULAN}

Ekstrak rimpang temulawak menghambat prolliperasi sel-sel otak besar secara nyata pada konsentrasi 100 ppm, tetapi ekstrak rimpang temulawak mampu meningkatkan pertumbuhan panjang akson dan dendrit pada konsentrasi 400 ppm.

\section{UCAPAN TERIMAKASIH}

Ucapan terimakasih disampaikan kepada MENRISTEK yang telah mendanai penelitian ini melalui Dana Insentif Terapan Ristek tahun 2010-2011.

\section{DAFTAR PUSTAKA}

Affari, L. 2011. Otak tambah pintar dengan bersepeda.http://b2windonesia.or.id/bacanote/otak_tamb ah_pintar_dgn_bersepeda_tinjauan_ scienties [08 Oktober 2011].

Braak, H., Rub, U., Schultz, C. and Tredici, K. 2006. Vulnerability of cortical neurons to Alzheimer's and Parkinson's diseases. J Alzheimers Dis 9: 35-44.

Cheah, Y.H., Azimahtol, H.L.P., Abdullah, N.R. 2006. Xanthorrhizol exhibits antiproliferative activity on MCF-7 Breast cancer cell via apoptosis 
induction. Anticancer Research. 26: 4527-4534.

Choi, D.K., Koppula, S. and Suk, K. 2011. Inhibitors of Microglial Neurotoxicity: Focus on Natural Products. Molecules. 16:1021-1043

Colville, T., Bassert, J.M. 2002. Clinical Anatomy \& Physiology for Veterinary Technicians. United States of America: Mosby Inc.

Feriyawati, L. 2006. Anatomi sistem saraf dan peranannya dalam regulasi kontraksi otot rangka. Tesis. Sumatera Utara: Fakultas Kedokteran, Universitas Sumatera Utara.

Freshney, R.I. 2005. Culture of Animal Cells, A Manual of Basic Technique. $5^{\text {th }}$ edition. Hoboken N.J, John Wiley \& Sons, Inc.

Goldman, S. 2003. Glia as neural progenitor cells. Trends in Neurosciences. 26(11): 690-596.

Handayani, T. 2008. Pengaruh xanthorrhizol terhadap sel hepatoma HepG2. Jurnal Kedokteran Maranatha. 8(1):29-35.

Heleagrahara, N. and Ponnusamy, K. 2010. Neuroprotective effect of Centella assiatica extract (CAE) on experimentally induced parkinsonism in aged spraguedawley rats. Journal Toxicological Sciences. 35(1): 41-47.

Hong, R., Spohn, W.H., Hung, M. 1999. Curcumin inhibit tyrosine kinase activity of $\mathrm{P} 185^{\text {neu }}$ and depletes P185 ${ }^{\text {neu }}$. Clinical Cancer Research 5: 1884-1891.

Jayaprakasha, G.K.L., Rao, J. and Sakariah, K. 2006.Antioxidant activities of curcumin, demethoxycurcumin and bisdemethoxycurcumin, Food Chemistry 98: 720-724

Junqueira, L.C. and Carnerio, J. 2005. Basic Histology. $11^{\text {th }}$ edition. USA: The McGraw-Hill Companies Inc.
Kalverbour, A.F., Genta, M.L., Hopkins, J.B. 1999. Current Issues in Developmental Psychology. Neteherlands: Kluwer Academic Publisher.

Kim, S.J. et al. 2008. Curcumin stimulates proliferation of embryonic neural progenitor cells and neurogenesis in the adult hippocampus. The Journal of Biological Chemistry 283(21): 14497-14505.

Kuntarti. 2007. Anatomi sistem saraf. http:// staff.ui.ac.id/internal/ 1308050290/material/anatomisaraf. pdf. [16 Maret 2011].

Le Roux, P.D. and Reh, T.A. 1994. Regional differences in glial-derived factors that promote dendritic outgrowth from mouse cortical neurons in vitro. The Journal of Neuroscience 14(8): 4639-4655.

Paradis, E., Douillard, H.L., Koutroumanis, M., Goodyer, C. and LeBlanc. A. 1996. Amyloid b Peptide of Alzheimer's Disease Downregulates Bcl-2 and Upregulates Bax Expression in Human Neurons. The Journal of Neuroscience. 16(23): 7533-7539.

Putranto, P.L. 2009. Pengaruh senam otak terhadap fungsi memori jangka pendek anak dari keluarga status ekonomi rendah. Tesis. Semarang: Universitas Dipenogoro.

Ramos, D.A.C. and Shen, K. 2008. Cellular Conductors: Glial Cells as Guideposts during Neural Circuit Development. PLoS Biol 6(4): 112. doi:10.1371/journal.pbio.0060112.

Riyacumala, V. 2010. Kultur in vitro selsel otak besar (cerebrum) anak tikus. Skripsi. Bogor: Fakultas Kedokteran Hewan, Institut Pertanian Bogor.

Soumyanath, A., Zhong, Y.P., Gold, S.A., Yu, X., Koop, D.R., Bourdette, D., Gold, B.G. 2005 J Pharm Pharmacol 57(9):1221-9 (ISSN: 0022-3573).

Sushma, T., Sangeeta, G., Gambhir, I.S. 2010. Centella asiatica: A concise 
Fitofarmaka, Vol. 1 No.2, Pebruari 2011: 1 - 8

drug review with probable clinical

and Biochemistry. 7: 38-44.

uses. Journal of Stress Physiology 